\section{COVID-19: community CPAP and NIV should be stopped unless medically necessary to support life}

\author{
Joseph Barker (10, ${ }^{1}$ Oluwatobiloba Oyefeso, ${ }^{2}$ David Koeckerling, ${ }^{3}$ \\ Nadeesha Lakmal Mudalige, ${ }^{4}$ Daniel Pan $^{5}$
}

Dear Editor,

Data from the severe acute respiratory syndrome coronavirus 1 (SARS-CoV-1) outbreak suggest high viral load at the time of transmission is associated with worse clinical outcomes. ${ }^{1}$ Non-invasive ventilation (NIV), including CPAP, is currently listed by the $\mathrm{WHO}$ as a high-risk aerosolgenerating procedure putting healthcare workers at risk and necessitates the use of personal protective equipment. ${ }^{23}$

The current UK guidance does not account for high-dose viral transmission risk to family and carers in patients using community NIV and CPAP for treatment of chronic respiratory disease, especially obstructive sleep apnoea.

National Health Service guidance states for patients who remain at home during the coronavirus pandemic to continue with their usual method of ventilation. ${ }^{4}$ The British Thoracic Society guidance for obstructive sleep apnoea advocates patient choice to determine implementation of distancing measures while using CPAP or stopping CPAP for a short time. It goes on to encourage patients to persist with CPAP when experiencing symptoms of respiratory infection. ${ }^{5}$

Zou and colleagues reported comparable severe acute respiratory syndrome coronavirus 2 (SARS-CoV-2) viral load detection in nasal and throat swabs of symptomatic and asymptomatic patients, suggesting NIVinduced aerosolisation of nasopharyngeal

\footnotetext{
${ }^{1}$ Department of Cardiovascular Sciences, University of Leicester, Leicester, UK

${ }^{2}$ Department of Primary Care, Royal Free London NHS Foundation Trust, London, UK

${ }^{3}$ Department of Medical Sciences, University of Oxford, Oxford, UK

${ }^{4}$ Department of Population Health, London School of Hygiene \& Tropical Medicine, London, UK

${ }^{5}$ Department of Respiratory Sciences, University of Leicester, Leicester, UK
}

Correspondence to Dr Joseph Barker, University of Leicester, Leicester LE1 7RH, UK; joseph.barker@nhs.net secretions from asymptomatic patients may pose similar risks for high-dose viral transmission in households. ${ }^{6}$ Aerosolised SARS-CoV-2 is reported to have a half-life of 1.1 hours in air and therefore a period of prolonged isolation may be required following NIV usage. ${ }^{7}$ Universal isolation for NIV and CPAP usage within households may not be practical and individualised consideration should be given to temporary cessation of community ventilation, taking into account the risks of withholding NIV in hypercapnia. ${ }^{8}$

While we agree that data are limited, we believe the risk of high-dose viral transmission of SARS-CoV-2, from community NIV and CPAP users to household members, to be highly plausible and with potentially severe consequence. In the interests of patients' families and their carers we call for a consensus opinion on clearer instructions for patients and their physicians-how to isolate while using NIV or CPAP at home, safety provisions for household members and risk-benefit analysis of temporary NIV or CPAP cessation.

A response by Baker and Sovani to the views expressed here has also been published in Thorax. ${ }^{9}$

\section{Twitter Joseph Barker @jarbark}

Contributors All authors contributed equally to manuscript authorship and revision.

Funding The authors have not declared a specific grant for this research from any funding agency in the public, commercial or not-for-profit sectors.

Competing interests None declared.

Patient consent for publication Not required.

Provenance and peer review Not commissioned; internally peer reviewed.

This article is made freely available for use in accordance with BMJ's website terms and conditions for the duration of the covid-19 pandemic or until otherwise determined by BMJ. You may use, download and print the article for any lawful, non-commercial purpose (including text and data mining) provided that all copyright notices and trade marks are retained.

(C) Author(s) (or their employer(s)) 2020. No commercial re-use. See rights and permissions. Published by BMJ.

D Check for updates

To cite Barker J, Oyefeso 0, Koeckerling D, et al. Thorax 2020;75:367.

Published Online First 9 April 2020

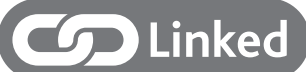

- http://dx.doi.org/10.1136/thoraxjnl-2020-214913

Thorax 2020;75:367.

doi:10.1136/thoraxjnl-2020-214890

ORCID iD

Joseph Barker http://orcid.org/0000-0002-5483-9608

\section{REFERENCES}

1 Chu C-M, Poon LLM, Cheng VCC, et al. Initial viral load and the outcomes of SARS. CMAJ 2004:171:1349-52.

2 Tran K, Cimon K, Severn M, et al. Aerosol generating procedures and risk of transmission of acute respiratory infections to healthcare workers: a systematic review. PLoS One 2012;7:e35797.

3 World Health Organization(WHO). Rational use of personal protective equipment (PPE) for coronavirus disease (COVID-19), 2020. Available: https://apps.who. int/iris/bitstream/handle/10665/331498/WHO-2019nCoV-IPCPPE_use-2020.2-eng.pdf

4 NHS. Clinical guide for the use of acute non-invasive ventilation in adult patients hospitalised with suspected or confirmed coronavirus during the coronavirus pandemic, 2020. Available: https://www.england.nhs. uk/coronavirus/wp-content/uploads/sites/52/2020/03/ clincial-guide-acute-niv-ventilation-v1-19-march-2020. pdf [Accessed 23 Mar 2020].

5 Society BT. Guidance regarding coronavirus (COVID-19) and obstructive sleep apnoea (OSA): for people who routinely use continuous positive airway pressure (CPAP), their families and health care workers, 2020. Available: https://www.brit-thoracic.org.uk/media/ 455098/osa-alliance-cpap-covid-19-advice-20-3-20v10.pdf

6 Zou L, Ruan F, Huang M, et al. SARS-CoV-2 viral load in upper respiratory specimens of infected patients. N Engl J Med 2020;382:1177-9.

7 van Doremalen N, Bushmaker T, Morris DH, et al. Aerosol and surface stability of SARS-CoV-2 as compared with SARS-CoV-1. N Engl J Med 2020. doi:10.1056/NEJMc2004973. [Epub ahead of print: 17 Mar 2020].

8 Köhnlein T, Windisch W, Köhler D, et al. Non-Invasive positive pressure ventilation for the treatment of severe stable chronic obstructive pulmonary disease: a prospective, multicentre, randomised, controlled clinical trial. Lancet Respir Med 2014;2:698-705.

9 Baker JG, Sovani M. Case for continuing community NIV and CPAP during the COVID-19 epidemic. Thorax 2020;75:368 